\title{
Colleges of Education System and MDGS: Redirecting the Focus towards Achieving the MDGS
}

\author{
Charles Ngozi Ugwuegbulam \\ Ph.D, School Of Education, Alvan Ikoku Federal College Of Education, Owerri- Imo State, \\ Nigeria \\ Mrs. Helen Ijeoma Ugwuegbulam \\ School Of Social Sciences, Alvan Ikoku Federal College Of Education, Owerri- Imo State, \\ Nigeria
}

Accepted: Jan 05, 2013 Published: Feb 23, 2013

Doi:10.5296/jsr.v4i1.3293 URL: http://dx.doi.org/10.5296/jsr.v4i1.3293

\begin{abstract}
The millennium Development Goals (MDGs) are goals the world wants to achieve. Each country is striving to achieve the eight goals but the extent and rate at which they are going about it differs. Most countries leave the pursuit of the goals to their government. In Nigeria, the story is not too different. Nigeria has made some visible and notable strides toward the achievement of the MDG goals yet there are still much to be done. Since education is an instrument for national development in Nigeria, it is the intention of this paper to view how the college of education system can contribute to the achievement of the MDGs. In doing this, the MDGs were identified and those that are amenable to be achieved through the college of Education system were briefly discussed, pointing out the available resources and the add-ons that could help to achieve the goals.
\end{abstract}

\section{Introduction}

The Millennium Development Goals are goals the countries of the world have agreed to pursue and achieve both for the good of their countries as well as that of the world. The goals are expected to be achieved by 2015. Looks at the status quo of countries in the extent to which they are achieving the goals vary. Some countries are very near to achieving the goals while some are dangerously distant from achieving the goals. Others are making modest push and achievements with regards to accomplishing the goals. Nigeria as one of the countries of the world is not left out in striving to achieve the Millennium Development Goals, however, evidences indicated that there are still much to be done to get there. In this wise therefore, it is thought that more efforts should be expended to achieve the goals. In view of the fact that 


\section{Macrothink}

Nigeria uses education as an instrument for national developments this paper reasons that, teacher education could have a stake in moving things to achieve the millennium development goals. In doing this, the paper focused on what the colleges of education in Nigeria can contribute in that wise. Nigeria has made some strides to achieving the MDGs, selected four MDGs which the authors think their achievements can be forged by the over 60 Colleges of Education in Nigeria.

\section{What Are The Millennium Development Goals (Mdgs)}

The millennium development goals are eight international development goals that all the 193 UN member states and at least 23 International Organizations agreed to achieve by the year 2015. (en.wikipedia.org/wiki/millenniumd_Devpt_Goals retrieved on 5/10/12). These goals were endorsed at the United Nations by members states in 2000. The goals "aim to improve human well-being by reducing poverty, hunger, child and maternal mortality, ensuring education for all, controlling and managing diseases, tackling gender disparity, ensuring sustainable development and pursuing global partnerships" (www.greenfacts.org/glossary/mno MDGs-millennium-development goals htm retrieved on $5 / 1012)$.

The millennium development goals, as mentioned above, are eighty in number. Each goal has target (s) as well as indicators which are used as gauge to determine the extent of the achievement of each goal. Below are the eight goals with their targets extracted from www.un.org/millenniumgoals .

\section{GOAL 1}

Eradiate extreme poverty and hunger.

\section{Target 1a.}

Halve, between 1990 and 2015, the proportion of people whose income are less than $\$ 1$ a day.

\section{$\underline{\text { Target } 1 b}$}

Achieve full and productive employment and decent work for all, including women and young people.

\section{$\underline{\text { Target 1c }}$}

Halve, between 1990 and 2015, the proportion of people who suffer from hunger.

\section{GOAL 2}


Achieve universal primary education.

\section{Target 2a}

Ensure that, by 2015, children every where, boys and girls alike, will be able to complete a full course of primary schooling.

\section{GOAL 3}

Promote gender, equality and empower women.

\section{Target 3a}

Eliminate gender disparity in primary and secondary education, preferably by 2005 , and in all levels of education not later than 2015.

\section{GOAL 4:}

Reduce child morality

\section{Target 4a}

Reduce by two thirds, between 1990 and 20015, the under-five morality rate.

\section{GOALS 5}

Improve maternal health.

\section{Target 5a}

Reduce by three quarters the maternal mortality ratio.

\section{$\underline{\text { Target 5b }}$}

Achieve universal access to reproductive health.

\section{GOAL 6}

Combat HIV/AIDS, Malaria and other diseases.

\section{Target 6a}

Have halted by 2015 and begun to reverse the spread of HIV/AIDS. 


\section{Target 6b}

Achieve by 2010, universal access to treatment of HIV/AIDS for all those who need it.

\section{Target 6c}

Have halted by 2015 and begun to reverse the incidence of malaria and other major diseases.

\section{GOAL 7}

Ensure environmental sustainability.

\section{Target 7a}

Integrate the principles of sustainable development into country policies and programmes and reverse the loss of environmental resources.

\section{Target 7b}

Reduce biodiversity loss, achieving, by 2010 a significant reduction in the rate of loss.

\section{Target 7c}

Halve, by 2015, the proportion of population without sustainable access to safe drinking and basic sanitation.

\section{$\underline{\text { Target 7d }}$}

By 2020, to have achieved a significant improvement in the lives of at least 100 million slum dwellers.

\section{GOAL 8}

Develop a global partnership for development.

\section{Target 8a:}

Develop further an open, rule-based, predictable, non-discriminatory trading and financial system.

\section{Target 8b:}


Address the special needs of least developed countries.

\section{Target 8c:}

Address the special needs of landlocked developing countries and small Island developing states.

\section{Target 8d:}

Deal comprehensively with the debt problems of developing countries.

\section{Target 8e:}

In cooperation with pharmaceutical companies, provide access to affordable essential drugs in developing countries.

\section{Target 8f:}

In cooperation with the private sector, make available benefits of new technologies, especially information and communication.

\section{Extent Of Progress Of Achieving MDG Goals In Nigeria}

Nigeria has made some progress in trying to achieve the MDGs so far but there are still things to be done. In view of the title of this paper, the MDGs that will be focused upon are those which the writer thinks the Colleges of Education can help to achieve through their mandate of producing teachers for basic education in Nigeria. Giving this premise, four MDGs will be the focus. The four MDGs to be discussed are:

- Eradication of extreme poverty.

- Achieving universal primary education.

- Promoting gender equality and empowerment of women, and

- Combating HIV-AIDS, Malaria and other diseases.

\section{a) Eradication of Extreme Poverty}

Report has it that there is evidence of economic growth especially in the area of agriculture the gains in agriculture is presently being threatened in the face of flood in most part of Nigeria. Farm-lands have been dealt with by flood. This sets the stage for possible hunger in the years to come. There is increased reduction in the proportion of underweight children from 35.7percent in 1990 to 23.1 percent in 2008(www.undp.org /mdgniprogress.shtml retrieved on 6/10/12). The document, 
while acknowledging the growth lamented that the growth has failed to generate enough jobs and its effect on poverty is not yet clear. The document further revealed that the available data and the current policy on environment suggest that the target will be difficult to meet and therefore suggests that social protection and poverty eradication programmes need to be scaled-up and better coordinated.

\section{b) Achieving Universal Primary Education}

Much has been invested toward achieving universal primary education in Nigeria. It is reported that 9 out of 10 children are now enrolled in schools (www.ng.undp.org/mdgsnprogess.shtml retrieved on 6/10/12). The document asserts that state primary completion rates range from 2 percent to 99 percent. In addition, the document noted that the rapid improvement in youth literacy which rose from $64.1 \%$ to $80 \%$ from 2000 to 2008 has reached a plateau. By extension, more need to be done to achieve a $100 \%$ target. The document credited the modest achievement so far made with respect to the MDG goal number 2 to the Federal Teachers Scheme and in-service training out in place annually by the National Teachers institute. Despite the above, there is need to accelerate progress towards achieving this goal via Colleges of Education system.

\section{c) Promoting Gender Equality and Empowerment of women.}

On this issues some significant gains have been made as the proportion of girls enrolled into the basic education level in Nigeria has increased, although not yet enough to meeting the target. (www.ng.undp.org /mdgnprogress.shtml retrieved on 6/10/12). The above translates to the fact that there are fewer girls than boys in primary schools in Nigeria. This is the general picture in Nigeria but not true of the South-East geo-political zone in Nigeria. In the South-East, the boys drop out of school as if it is the norm. The document in reference suggests that, to encourage more girls to attend schools, the cultural barriers, especially in the northern part of the country, should be addressed while the boys from the South-East geopolitical zone can be kept in school if economic incentives are provided for them in their schools. This calls for practical, life-experience entrepreneurship education. The document in reference noted that currently, fewer women hold political offices but expects a future from the policy framework of giving more than $30 \%$ of political offices to women in Nigeria.

\section{d) Combating HIV/AIDS, Malaria and Other Diseases}

There is a 98\% success story between 2009 and 2010 in the eradication of polio. In the case of HIV, some degree of success has been recorded as evidenced by the HIV sero-prevalence rate of $5.8 \%$ in 200 and $4.2 \%$ in 2008 among pregnant young women aged 15-24 years. UNDP Nigeria also revealed that there has been sharp 
decrease in malaria and tuberculosis prevalence rates. The document suggested that to consolidate and extend the gains especially in the case of HIV-AIDS, that there should be improved knowledge and awareness of HIV/AIDS. The improvement of HIV/AIDS knowledge and awareness can be done to equip teacher trainees in college of education. These can have protective function on them and also equip them to educate the learners that would be placed under their care.

\section{Redirecting The Focus In Colleges Of Education In Nigeria Towards Achieving The Millennium Development Goals}

There are over 82 Colleges of Education in Nigeria out of which 21 of them are designated as Federal College of Education. The rest are either owned by State Government or private individuals. All these Colleges of Education are under the direct supervision of the National Commission for Colleges of Education (NCCE) who monitor and maintain standards in these institutions among other responsibilities. Colleges of Education in Nigeria have a primary charge to produce "highly qualified non-graduate teachers" who will man the basic education level in our educational system with their Nigeria Certificate in Education (NCE). The Colleges of Education in Nigeria produce over 7,000 NCE graduates annually who are to teach at the basic education level. These teachers, if employed, would impact much on the learners at their young ages with a possible transfer effect to adulthood. The knowledge, skills and attitude acquired during training in college will help the teachers work effectively and efficiently.

The lecturers in our Colleges of Education use the NCE minimum standard as guide in producing NCE teachers. The provisions in some of the minimum standard provided by the NCCE are pre-disposed to contributing towards achievement of some of the millennium development goals. Some of the lecturers handle these provisions from purely academic stand point without practical implications that could facilitate the realization of some of the MDGs from the classroom. The goals are not things for the Federal and State Government to achieve alone; individuals and Institutions equally have roles to play. It is on this reason that the Colleges of Education system in Nigeria should have a stake and should contribute their own quota.

\section{College Of Education And Eradication Of Poverty And Hunger}

The Colleges of Education in Nigeria have the provisions with which to work towards the eradication of poverty and hunger. Poverty in this content is seen as a state of not having money to feed and meet up with personal needs of self while hunger is a state were one has very little or nothing to eat. These two situations can be ameliorated by the College of Education in Nigeria. The NCCE has made provisions in their minimum standards for Colleges of Education for the teaching of Entrepreneurship Education as a General Studies Course. One of the primary purpose for inclusion of this course in the NCCE guideline is to equip NCE graduates to be able to employ self on graduation since there is high 
unemployment rate in Nigeria and elsewhere. Presently, this course is taught as "Just one of the courses to be taught to NCE student before they graduate from college. The practical aspect that would make it relevant is usually overlooked. This may be because there is no enough time provision for that. The idea of teaching entrepreneurship education course as a standalone course, with its merits, should be retained. However, this paper advocates a situation where an infusion approach could be considered. In the proposed infusion approach, the lecturers while teaching the course contents of their courses should point out the ethical enterprise such course contents, along or in conjunction with other course contents, would lead to. By this, the students interest will be awakened and sustained in such courses because of its perceived relevance. This could translate into higher academic performance in the students. Given the above scenario, the student is very likely to start a business based on the saw courses learnt. By that, they will be self-employer of labour. Such students are not likely to be poor and can fend for self. Given the crude statistics that about 7000 NCE graduates are produced every year, these potential unemployed NCE holders, would have been empowered and employed self and maybe others who would have been dependent persons. They can be self employed if they know the importance of their subjects, persons who need the services from the subject and reach out to those who nee it. A mathematics NCE graduate, without a job can produce a filer about home service as a specialist mathematics teachers and share to the public. He/she is likely to get patronage. As teachers, a situation where they are employed to teach, would offer them the opportunity to translate the entrepreneurship spirit to their own learners. In primary schools, collect hard work money from pupils instead of encouraging them to produce things. The objective of producing physical things for handwork is to provide learners with skills which they will appreciate. The materials produced by learners like broom, baskets etc can be sold by learners, thereby generating income for them. Cumulatively, poverty and hunger would be exiled from them.

\section{Colleges Of Education And Achievement Of Universal Primary Education}

Nigeria has made significant strides towards the achievement of universal primary education but is short of the 2015 MDG target. In the area of access to primary education, the Colleges of Education and their students have little or nothing to do towards the achievement of universal primary education for all by 2015 . However, in the areas of retention, completion and performance the teachers produced by the College of Education can do some things. Their institutions should teach them that the following strategies as stipulated by FME (2007) could help retain girls in schools by given them.
a) Second chance education pogramme,
b) Girl child encouragement clubs, and
c) Reproductive Health Education.

In the South-East geo-political zone of Nigeria, one of the problems in basic education is that there is high drop-out rate of boys. The Colleges of Education in that area should equip their teacher trainees with skills and knowledge of what to do to retain boys in schools. Again, 
Colleges of Education should add to the content of entrepreneurship Education course the idea of starting and running cooperative societies. In addition, the strategies suggested by Ike-Obioha (1998) for encouraging males enrolment in schools should be taught to trainee teachers. These strategies include the following:

1. Teaching students to acquire technical skills for employment especially at the last 3 years of basic education. The can be done and achieve through introductory technology, one of the subjects offered in the junior secondary school classer.

2. Involving students in meaningful activities in the school like in different aspect of agricultural.

3. Teaching of desired trades and vacation in the school. This can be pursued through exposing learners to career fairs and days etc.

4. Encouraging students by providing scholarship schemes for boys. The scholarships could be sourced from philanthropists in the comities. The scholarship has the potency of enabling them to complete their studies if finance is the constraint.

5. Honouring well behave boys in school during parents' day.

6. Making learning interesting through student activity oriented programmes.

The implementation of the above are deemed to help retain boys in schools especially in Abia, Anambra, Ebonyi, Enugu and Imo State. The institutions should teach their trainee teachers how to best implement the strategies. This will move Nigeria forward to achieve these Universal Basic Education target set for 2015.

\section{Colleges Of Education And Promotion Of Gender Equality And Women Empowerment}

The Nigerian culture had high dosage of gender inequalities, biases, discrimination and insensitivity. They lived in our homes and extended to both schools and offices. These had long being recognized and steps are being taken to reduce them if not eliminate them and it is succeeding. Before now, girl enrolment in schools were grossly nothing to write home about. Females were hardly seen being heads of institutions and parastatals. These days, things are changing for good but the marks of equity and equality are yet to be reached. The improvement may be attributed to strategies the Federal Ministry of Education (2007) structured to help out in the circumstance of gender inequality and lack of women empowerment. Give the scenario that it is not yet uhuru in the promotion of gender equality and women empowerment, Colleges of Education in the country should appoint both males and females into positions of authority within the school to a ratio of 3:2 They should work with the student union by reserving certain positions like vice president, catering, treasurer etc for females during students union elections while encouraging them to vie for other positions. Since winning an elective position into the Students Union government is by majority vote and since most of the College of Education, especially as South-East geo-political zone have more females students, what stops them from voting themselves into power? In addition, a elective course in gender sensitivity and gender responsiveness should be made compulsory for all students running NCE programme. This will put all 
students on the same pedestal as it concerns gender issues. Finally, Colleges of Education should have a twin centre for gender studies and entrepreneurship established in their institutions.

\section{Colleges Of Education And Combat Of Hiv-Aids, Malaria And Other Diseases}

Nigeria's HIV-prevalence which was $5.8 \%$ in 2001 was reported to be $4.2 \%$ in 2008. This may be as a result of what the Federal and State Governments put in place to combat HIV-AIDS. The HIV/AIDS desk officers should have programmes that include assessment of risky behaviours, life skills with emphasis on assertive training, negotiation skills, abstinence etc. this activities/training could be done in conjunction with the college counselors working in the counseling centres. This will help to make the service reach many of the trainee teachers. Although the Sero-prevalence is $4.2 \%$, a situation of near zero \% will be highly appreciated. In this circumstance, Colleges of Education could contribute in the reduction of HIV/AIDS prevalence rate by having active desk officers for HIV-AIDS with programmes that are purposeful and meaningful. Apart from that, the teaching of Family Life and Emergent Health Issues (FLEHI) should be taught with special emphasis on the aspect of HIV-AIDS. By this, the students are likely to acquire knowledge and skills for HIV Prevention. These they can also transfer to their students when they go out to teach. Furthermore, Ugwuegbulam (2002) had identified some factors that could lead students into having sexual intercourse which, if unprotected and with an infected person would put the uninfected at risks of being infected. These factors include unassertiveness, poverty, insatiability, peer influences and desire to belong and do what the peers are doing etc. the college desk officer and counselors should be giving talk to students in their departments as well as weave it into student unions activities.

In terms of combating malaria, the colleges could apply for long lasting insecticide-treated bed nets for their students especially those living in the hostels. The clean-up exercises which is one of the features of Nigeria governments should be copied and done properly in the colleges. This will make the college environment clean, safe and health for living.

\section{Conclusion}

This paper has highlighted the eight millennium development goals and identified four of them which, to the writer, the Colleges of Education system can help to achieve. To do this, curricular provisions in the NCE programmes were identified as vehicle for moving towards the achievement of the goals; some activities were also suggested to supplement the already existing provision. All these have their attendant implications.

\section{References}

Adeyinka, A.A. (1971). History of Education Mimeograph. 


\section{Macrothink}

en.wikipedia.org/wiki/Millennium_Development_Goals retrieved 5/10/12.

Fajana .A. (1978). Education in Nigeria, 1847-1930. a historical analysis. Longman printing press.

Federal Ministry of Education. (2007). National Policy on Gender in Basic Education. Abuja.

Ike-Obioha, B. (2006). Strategies for Encouraging Male Enrolment in Imo State Secondary Schools. Eastern Coeasu Journal of Teacher Education (ECOJOTE) 2(2) pp. 89-96.

Jekayinfa, A.A. (1992). Development of Teacher Education. Occational Publication 1, Unilorin, facility of Education.

Ugwuegbulam, C.N. (2002). HIV/AIDS Guidance Services. Owerri. V Versatile Publishers. 